\title{
Japan's Evolving Nested Municipal Hierarchy: The Race for Local Power in the 2000s
}

\author{
A. J. Jacobs \\ Department of Sociology, East Carolina University, 405A Brewster, MS 567, Greenville, NC 27858, USA \\ Correspondence should be addressed to A. J. Jacobs, drajjacobs@yahoo.com
}

Received 8 October 2010; Accepted 10 December 2010

Academic Editor: Ben Derudder

Copyright ( 2011 A. J. Jacobs. This is an open access article distributed under the Creative Commons Attribution License, which permits unrestricted use, distribution, and reproduction in any medium, provided the original work is properly cited.

In agreement with Nested City theory, this paper illustrates how Japan's municipal hierarchy has evolved and remained embedded within that nation's particular historical-political-economic context. It chronicles how municipalities have attained status based upon the role they have played in the country's political, economic, and military history, and, more recently, their population size. It then shows how during the post-war period, the tiers within this urban stratification system were expanded and institutionalized by national laws governing municipalities. Drawing upon more than 100 interviews with local government officials in nine prefectures, it then reveals how a shift in national policy toward decentralization in the late-1990s sparked a race for higher municipal status in Japan's national hierarchy, during the 2000s, and thereby, local power.

\section{Introduction}

Since the issuance of the second edition of Hall's [1] World Cities in 1979, and the subsequent publications of Cohen [2] and Friedmann and Wolff [3], the urban scholarship has debated whether or not globalization has deterritorialized cities from their national urban systems. For the most part, there has been a fair amount of agreement that contemporary capitalism, under the direction of transnational corporations (TNCs), has disembedded and reorganized the globe's cities into a new international division of labor or world system of cities. Only a group of scholars studying East Asian cityregions have objected to this seemingly fait accompli. These Nested City theorists have claimed that while urban areas in Japan, South Korea, and Taiwan have been impacted by global economic forces, the central state has retained primacy over urban growth trajectories and processes in these nations. In other words, they have maintained that East Asian cities have not been disembedded from their particular national urban hierarchies, nor have they been reterritorialized into a world city network in which their national government has had no control over.

So which view best reflects the situation of Japanese cities? Concurring with Nested City scholars, and draw- ing upon historical changes to local government law and interviews with more than 100 nonelected officials in nine prefectures, this paper argues that Japanese cities have remained embedded within a centralized intergovernmental system which has managed their size, functions, and degree of local authority. It demonstrates this by chronicling how, over time, municipalities have attained status based upon their role in the country's political, economic, and military history, and, more recently, their population size. In then reveals how, during the postwar period, the number of tiers within the nation's municipal stratification system was significantly expanded and institutionalized by national laws governing municipalities. Coupled with a post-1995 national policy shift favoring decentralization, this evolving context sparked a race for higher municipal status in Japan's national hierarchy during the 2000s, and thereby, expanded local power.

Overall, this study seeks to provide new insight into Japan's interlocal system, and in doing so, it hopes to help dispel some of the myths that scholars have about that nation's municipalities, especially in the West. Its conclusions also should prove useful to scholars interested in the role that national governments play in the shaping of national and international urban networks/systems. 


\section{A World System of Cities or Nested Urban Hierarchies?}

Although critical of the theory's lack of empirical data, Derudder et al. [4] wrote

One of the most salient propositions in John Friedmann's seminal World City Hypothesis... refers to the fact that key cities throughout the world are used by global capital as basing points in the spatial organization and articulation of production and markets. The resulting linkages make it possible to arrange world cities into a complex spatial hierarchy (page 875).

In other words, Friedmann [5], similar to other wellknown Global City/World City Systems theorists, most notably, Sassen [6, 7], Knox and Taylor [8], Smith and Timberlake $[9,10]$, and Taylor $[11,12]$, argued that global capital flows, dictated by multinational corporations (MNCs), have gained primacy over urban development processes and outcomes (i.e., growth trends and spatial patterns, etc.). These forces have then created a new international division of labor which has effectively disembedded cities from their nation states and reorganized municipalities into a global urban hierarchy.

At the top of this stratification system have been the "global cities": New York, London, and Tokyo, which as a result of their "extraordinary concentrations of top corporate decision-makers," have become the world's headquarters for international finance, production, and trade [13, page 3]. Taylor, Timberlake, and their colleagues have spent the past 15 years empirically verifying which cities have commanded the greatest authority and delineating linkages among firms and places in this world city system [1419].

Despite these interesting and powerful pronouncements, as Abu-Lughod [20] and Smith [21] contended, one of the critiques of World/Global City theory has been that its advocates have frequently failed to incorporate a truly historical perspective into their taxonomy. One of the few exceptions to this was Chase-Dunn [22]. Addressing this, in true Wallersteinian fashion, he wrote that despite the claims of some Global City advocates, "the system of world cities... did not appear in the 1950's, with cities having been "national" before that time. Rather, cities have long been both national and international" [22, page 273]. On the other hand, the perceived absence of historical context among World/Global City theorists has provoked numerous studies offering alternative theses to explain the continued differentiation among world cityregions.

The primary counter argument has come from the Nested Cities thesis. The central place theorist Preston [23], in the seminal edited volume by Bourne and Simmons [24] on systems of cities, used the term nested hierarchies to describe the functional interdependency among municipalities within nations. Similarly, Nested City theorists, led by Hill and Fujita [25], have rejected the claim that global forces have deterritorialized urban areas from their nation states and national urban hierarchies. Drawing their evidence from East Asian cities within developmental states, most frequently Tokyo, these authors have claimed that municipalities have remained tightly nested within their national and subnational contexts [2648].

According to Hill [26], hierarchy has two meanings in social science. Befitting the world city hypothesis, the first has viewed hierarchy as a top-down, vertically controlled relationship. Conversely, the situation in Japanese cities has represented a second meaning, in which there was "the nesting of parts within larger wholes" (page 374). Related to this, Hill and Fujita [25] wrote that "Tokyo, for example, is nested in relationships with the Tokyo Metropolitan Government, the Kanto region, [and] Japan's unitary and developmental state... New York, [on the other hand], has nested ties of an entirely different political and cultural sort" (page 213). As such, they claimed that Tokyo's rise to World City status was not dictated by TNCs, but rather orchestrated by Japan's centralized, interventionist government as part of its calculated, postwar strategy aimed at enhancing its domestic economy. Furthermore, they stated that corporate headquarters and central management activities have become overconcentrated in Tokyo not because of global forces, but rather "because a powerful central government, controlling $65 \%$ of the nation's public revenues and wielding vast administrative powers, has been centered there" [27, page 188].

Finally, as Hill [26] stated, Nested City scholars have dismissed the idea that globalization and embeddedness have been mutually exclusive, claiming that nestedness has been "intrinsic to the globalization process... [and] growing interdependence in the global whole [has been] perfectly consistent with differentiation within and among cityregions" (page 374-5). Based upon these findings, these City scholars have concluded that while global forces may have expanded their influence relative to other scales, they have not become the decisive determinants of urban form and function [26-47].

Inspired by Nested City theory and more than 100 face-to-face interviews with nonelected officials in nine of Japan's prefectures conducted between 1997 and 2009, this paper demonstrates how (1) Japan's municipal hierarchy has evolved over time in response to its particular political-economic-social context and (2) its centralized, interventionist State has remained the primary conductor of this system. The foremost embedded factors have been national laws and central government policies which have granted varying degrees of local status and authority to municipalities based upon their population size. Other national initiatives have created new cities or fostered growth in targeted industrial cities which have then ascended in the nation's municipal hierarchy. Lastly, Japanese localities also have been accorded status/prestige as a result of the roles they have played in the nation's Imperial, military, political, and commercial-industrial history. Related to this, the origins of Japan's nested municipal hierarchy are presented in the next section. 


\section{The Historical Origins of Japan's Nested Municipal Hierarchy}

Japan's embedded historical-political-economic context, particularly the roles certain areas have played in its development, has greatly influenced the population size and authority of municipalities. This in turn, has helped to shape its present-day national municipal hierarchy and intercity network [37, 42, 49, 50]. Cities have grown, have been accorded status, and have gained economic and political benefits, protection, and influence, essentially based upon four historically nested factors: (1) they became the main settlements of Imperial, military, or bureaucratic rule; (2) they served as important ports and/or industrial centers during the country's modernization period; (3) in response to strategic policies decrees made by the feudal or civil national government; and/or (4) their local firms contributed significantly to the nation's postwar economic growth. Japan's three largest cities, Tokyo, Yokohama, and Osaka, as well as its historic capital, Kyoto, and the industrial powerhouse, Toyota City, illustrate how urban areas in that nation have been impacted by one or more of these factors [51-66].

For example, between 794 and 1868, Kyoto, currently Japan's sixth largest city, served as its Imperial Capital. For most of this period, this made it the nation's most important place in all aspects of political, economic, cultural, and social life. In fact, its name alone, which essentially translates to (national) capital, has conferred, for more than 12 centuries, its special historical position in Japan's urban hierarchy. Predating Kyoto by 150 years, Osaka, currently the nation's second largest city, also originally rose to prominence as an imperial city; it was then called Naniwa-kyo. However, its true ascent toward the top of the nation's urban hierarchy began in the late-16th Century, when the military ruler Hideyoshi Toyotomi built the then largest fortress in the land there. Thereafter, the new Shogun relocated his numerous vassals to the city, which provoked rapid commercial and residential development [51].

Conversely, Hideyoshi also commanded the demolition of hundreds of castles nationwide that had protected the feudal lords (daimyo) that he and his predecessor Nobunaga Oda had defeated in their run to power [52]. These actions and similar ones by the Tokugawa Shogunate (Bakufu), in the early 17th Century, relegated these now castleless towns to "provincial" status, a fate which essentially limited their future growth potential [53]. Meanwhile, Osaka became the "Manchester of the Far East", a city of 350,000, trailing only Edo (now Tokyo) in size, and serving as the nation's primary central hub for the distribution and sale of rice, Chinese silk, imported medicines and cotton, as well as copper, cotton cloth, oils, paper, firewood, charcoal, fish, fowl, and swords [54-56, 67]. Although its population was eventually surpassed by Yokohama in 1980, it has retained its status position as Japan's "Second City" into the 21st Century.

As for Yokohama, neither a feudal nor an imperial center, its climb to its current size and status in the nation's municipal hierarchy began in 1854, when, after more than 250 years of isolation, America forced Japan to sign the
Treaty of Kanagawa, and to open its borders to Western trade. It was then that the Bakufu designated Yokohama as the permitted port of entry for Westerners, a decision that would transform the small fishing village into the nation's doorway to international exchange, culture, and technology $[57,58]$. It also would later turn it into the dominant domestic shipping port and the primary intake point for the foreign machinery, iron, and steel imports supporting Japan's 20th Century war efforts $[57,59]$.

Following World War II, the city again served as one of the nation's leading foreign trade ports, vying for the nation's top spot with the ports of Kobe, Tokyo, and Nagoya [58-60]. This, along with its spatial embeddedness nearby Tokyo, has provoked rapid growth in the city since the 1950s. Presently, a city of 3.7 million inhabitants, Yokohama was Japan's largest legally defined municipality; it would rank second if the area formerly encompassing the City of Tokyo, Tokyo's 23 Tokubetsu-Ku (Special Municipal Wards), were classified as a city [61]. As will be discussed later, similar to Kyoto, Osaka, and Japan's other cities with more than one million residents, its size also has granted it special status in its national municipal hierarchy.

In addition to the placement of castles and ports, strategic national policy initiatives have been another decisive determinant shaping Japan's municipal hierarchy. Postwar examples of this have been the 1972 Industrial Relocation Promotion Law, and the 1970s-1980s central government policies to create Science Cities and Technopoles in provincial areas $[51,56,62,65,66,68]$. Perhaps the most influential national policy declaration for Japan's urban hierarchy, however, was promulgated in 1635: the alternative residence proclamation of Shogun Iemitsu Tokugawa. This required all daimyo to establish two residences, one in their own han (fief) and a second in the Bakufu's new capital, Edo. This system spawned the development of numerous castle, post, resort, port, and market towns nationwide, each serving the needs of the feudal lords and their entourages when traveling to and from Edo, which in turn, laid the foundation for the nation's contemporary intercity system [53]. For example, the post towns of Saitama, Kawasaki, and Hamamatsu have grown to become important regional centers in modern Japan, each with a population above 800,000 [68]. In contrast, the moving back and forth also served to drain the wealth and weaken the power of the daimyo, resulting in a decline in the status and growth potential of their home territories.

As for Edo, the alternative residency decree transformed it into the world's largest city by the 1720 s, with a population of roughly 1.3 million [36]. While Kyoto remained host to the Imperial Court, Edo became the center of power and culture. Its status as the "first city of Japan" was cemented permanently in 1868, when the restored Emperor Meiji's Government moved the Imperial Capital to the area and renamed it Tokyo, or "Eastern Capital". As the new unquestioned locus of political authority, Tokyo became the core of the new government's "rich country, strong army" agenda in which it sought to "catch-up" technologically, economically, and militarily to the West. This strategy, along with its related industrial development, pushed the city's 
population to over two million by 1920 . Over the proceeding 20 years, as legions of migrants poured in to work in the area's factories, and it annexed 82 neighboring towns and villages, the number of inhabitants in the City of Tokyo soared to 6.78 million.

As was the case in most of Japan's large cities, Tokyo's population precipitously declined during World War II, as the result of evacuations and casualties. Meanwhile, in 1943 , the city was stripped of its municipal status and local authority, and its administrative functions subsumed by Tokyo Prefecture. As will be discussed later in more detail, despite the loss of its city status, Tokyo's 23 Tokubetsu$K u$ have collectively remained atop the nation's municipal hierarchy for the entire postwar period. As a result, the area rebounded quickly in the 1950 s and 1960 s, peaking at 8.89 million in 1965 . Over the next 30 years their population declined by nearly one million, before a growth spurt in the 2000s returned them to a combined 8.87 million in 2010 . This total, as well as their total employment of more than seven million, was roughly 2.5 times greater than that of their nearest rival in either category.

A final example exhibiting how historically embedded factors have shaped Japan's municipal hierarchy over time, particularly related to the role local firms have played in its postwar national economic growth, has been the case of Toyota City. A small farming town known as Koromo prior to World War II, Toyota's fortunes changed dramatically beginning in the 1950s as the result of the rise of Toyota Motor (TMC). In 1960, a year the city was renamed in honor of its largest employer, the area had roughly 45,000 residents. By 1995, however, as TMC had become one the world's top five automotive manufacturers, and a key catalyst in the nation's export-oriented economic growth strategy, the city had grown to more than 340,000 residents. Three years later, recognizing its importance not only to its regional economy, but to Japan's as a whole, the central government granted Toyota City special status and authority in its national urban hierarchy as a "Core City". The criteria and significance of this status will be discussed later. Nonetheless, it should be pointed out here that according to the local government officials interviewed for this study, the Core City category was created in Toyota City's image [68].

In sum, Japan's nested historical, political, military, and economic context has been the prime catalyst driving the development of its national municipal system. However, according to local officials, it was not until 1889, when Japan's civil municipal government system was promulgated, that its municipal status hierarchy was formally institutionalized into law [68]. How this was accomplished is chronicled in the sections to follow.

\section{Prewar Laws and the Beginning of a Formal Municipal Hierarchy in Japan}

Municipal status and authority hierarchies based upon population size are not uncommon. Most American States use population as the primary criteria for granting certain levels of self-governance. In Florida and Ohio, for example, communities with 5,000 residents may be incorporated as a city. For the former, the milestone is 1,500 in rural counties of less than 75,000. In the latter, communities of less than 5,000 may be incorporated as villages. It is also important to note that in the USA, the extent of local authority granted to cities, towns/townships, and villages, such as taxing powers and the provision of urban services, varies by state. In addition, since the USA is a federal system, and municipalities are creations of the American States, the USA Government has never established legislation defining a municipality's status and powers based upon its population size and/or employment.

In contrast, the central government has been at the forefront of defining local home-rule in Japan's centralized/unitary state. Whereas local officials interviewed for this study emphasized the importance of recent changes to national Local Autonomy Law (Chiho Jichi Ho), they believed that variations in local control were initially firmly established during the early Meiji Period (1868-1912), when national authority was transferred from the Bakufu to the Imperial Government, and a civil bureaucracy and intergovernmental system was established [68].

With the advent of a civil government system in 1869 , the feudal states (kuni) and their smaller han were abolished and replaced with prefectural governments (with powers somewhere in between that of a USA state and a British region). Then, in 1878, the national government enacted three new laws: the Municipalities Formation Law, the Prefectural Assemblies Act, and the Local Tax Ordinance. The first of which officially divided prefectures into $K u$ (i.e., independent wards/quasicities in urban areas) and gun (districts/counties). The latter were further subdivided into cho and son (towns and villages, resp.).

Municipal law was again refined in 1888 with the passage of the Municipal Government Act. Created from a blending of Japanese customs and Prussia's local government system, this statute provided for the direct election of city assemblies, who then indirectly elected a mayor. Towns and villages, however, were not granted the right to elect assemblies, but were allowed to elect their own mayor, subject to the approval of the Prefectural Governor [69-71]. The Municipal Act also originated the process for formalizing a legal municipal hierarchy in Japan, as it contained specific criteria defining the authorization of and powers assigned to cities, town, and villages [68]. In order to become a city (shi), a locality needed a population of 25,000, whereas towns were considered densely populated areas of smaller size, and the remaining rural areas were designated as villages; unlike Florida or California, for example, no areas were left unincorporated.

On April 1, 1889, 32 communities, including Tokyo, Yokohama, Osaka, and Kyoto, were officially authorized as Japan's first shi. By the end of that year, Nagoya and six more cities were officially established, and the country's 71,314 communities were consolidated into 39 cities and 15,820 towns and villages [72]. Surprisingly, the largest cities of Tokyo, Osaka, and Kyoto initially had the most restrictive level of self-governance. According to Steiner [69], "they were not allowed to elect their own mayor, but had as their chief executives, the nationally appointed governors of the prefectures in which they were located" 
(page 44). City residents were granted free elections in 1898; only men could vote. Nonetheless, over the next 20 years, they remained under the watchful eye of their prefectural governors, serving themselves as administrative extensions of the national government. Gun chief executives also remained the appointed arms of the prefecture, in charge of implementing policy in towns and villages $[69,70,73]$.

During the 1920s and early 1930s, large cities were granted expanded autonomy, in order to address their ever growing more complex needs $[70,74]$. As part of these efforts, in 1932, the City of Tokyo annexed the 82 adjacent localities mentioned earlier, enlarging its territory roughly fivefold and increasing its number of administrative wards ( $k u$ with a small "k") from 15 to 35 [36]. Unfortunately, this situation was completely reversed during World War II, when, as part of the national government's mobilization efforts, local self-governance was abolished. This decision most dramatically impacted Tokyo, as it included the promulgation of a new law, in 1943, called the Code for the Tokyo Metropolis, which disbanded the city and other communities within Tokyo Prefecture (Tokyo-fu) and placed them under the direct supervision of the Governor of the newly established Tokyo Metropolis (or Tokyo-to). The Prefectural Governor and chief executives of Tokyo's $35 \mathrm{ku}$ then were replaced by appointees of the national Ministry of Interior (Naimusho) [36, 69, 75]. As the next section describes, the context for local governance and the forces shaping its national municipal hierarchy would again dramatically change following Japan's defeat in World War II.

\section{Postwar Laws Refine, Expand, and Firmly Institutionalize a National Municipal Hierarchy}

Following the war, on May 3, 1947, a new Local Autonomy Law (LAL) was put into effect. This, along with other ordinances restored administrative powers and functions to municipalities. LAL was preceded by a new code for Tokyoto, on March 15, 1947. Under this new ordinance, what has come to be called Tokyo Metropolitan Prefecture, was accorded special authority and status as Japan's capital. In the process, the 35 pre-war $k u$ of the former City of Tokyo were reorganized first into 22 , and shortly thereafter, into 23 Tokubetsu-Ku ( $K u$ with a capital "K"). Although $k u$ is generally translated as ward, in Tokyo's case, the Tokubetsu$K u$ are effectively made 23 separate special localities, somewhat comparable to New York's boroughs, yet still under the direction of the Tokyo Metropolitan Government (TMG); on municipal vehicles, signs, in English, and websites, they use the word city, such as Koto City and Kita City $[39,71,76]$.

Initially, the Tokubetsu-Ku were provided with similar authority to other cities in Japan. Additionally, in 1949, their residents were granted the right to elect municipal assemblies and chief executives. A 1952 amendment to LAL, however, narrowed their powers to a list of specifically defined functions as delegated by the TMG, such as the supervision of parks and recreational areas, libraries, public halls, and roads. They were not, however, authorized independent taxing power [69]. As a result, in practice, from 1945 until 1999, when Article 281, Section 2 of LAL was amended to reconcile their powers with that of ordinary cities, most of the 23 Ku's functional responsibilities, although implemented by them, were actually administered by the TMG $[68,77]$. Nevertheless, as the national center of bureaucratic, political, and economic power, the Ku collectively have continued to represent the apex of Japan's nested municipal hierarchy. This status has benefited them greatly, especially the most central $\mathrm{Ku}$, Chiyoda, Chuo, and Minato, affording them central government financial and policy support above and beyond that of all other municipalities in the country $[68,69,73,75$, 78-80].

During the mid-1950s, new amendments to LAL, along with the introduction of the Village and Promotion Law, further reconfigured Japan's municipal hierarchy by expanding the authority of very large cities and by offering small localities incentives to merge to create larger municipalities. In 1956, with Tokyo already granted special status of its own, the remaining five of the former "Big Six" cities with at least one million in population at the timeKyoto, Osaka, Yokohama, Nagoya, and Kobe-were officially recognized by the central government as the nation's second tier of important cities (see Table 1). This was accomplished through an amendment to LAL called the Special Regulations Concerning Big Cities, which officially authorized them as Seirei Shitei Toshi (Government Ordinance Designated Cities) and defined their newly expanded powers.

According to Isozaki [70], the organization and function of Designated Cities has differed from those of ordinary cities in that they have been delegated many of the duties normally handled by the prefectures. For example, they have served as the lead agency for land development and transportation policy planning within their prefectural delineated city planning areas, which contain from three to 16 other municipalities [37]. Once authorized, Designated Cities also were entitled to divide their territory into $k u$ (wards) with a small " $k$ ", delineated in order to more efficiently manage their territory on a subarea scale. For example, in 2010, Osaka had $24 k u$, Yokohama 18, Nagoya 16, and Kobe and Kyoto had $11 k u$ each. However, unlike Tokyo's Tokubetsu-Ku, the $k u$ officials in Designated Cities have been appointed by the mayor, rather than elected officials. Moreover, the scale in which they have implemented city policy has been much smaller; collectively, the $23 \mathrm{Ku}$ have consistently had more than 8 million residents, as compared with between 1.5 and 3.5 million in the five original Designated Cities.

When first promulgated, to be classified as a Designated City under Article 252, Section 19 of LAL, a municipality had to (1) be considered a major city in its region, (2) have a population of 500,000 or more, (3) have a density of greater than 2,000 persons per $\mathrm{km}^{2}$, and (4) have less than $10 \%$ of its employment in primary industries [69]. In codifying this new special city category into law, the central government not only pacified the Big Cities, but also effectively institutionalized population as a primary determinant for municipal status and autonomy; 45 years later, this policy would also essentially encourage a soughtafter reduction in the number of municipalities. 
Table 1: Tokyo's 23 Ku, Japan's Seirei Shitei Toshi (Government Ordinance Designated Cities) $)^{(1)}$.

\begin{tabular}{|c|c|c|c|c|c|c|}
\hline & City & Prefecture & Date incorporated & Date authorized & $\begin{array}{l}\text { Population at } \\
\text { authorization }\end{array}$ & $\begin{array}{c}\text { Population } \\
\text { April 1, } 2010\end{array}$ \\
\hline & Tokyo $23 \mathrm{Ku}^{(\mathrm{T})}$ & Tokyo-to & 1889-Apr 1 & 1943-Jul 1 & $4,177,548$ & $8,868,642$ \\
\hline 1 & Yokohama & Kanagawa & 1889-Apr 1 & 1956-Sep 1 & $1,143,687$ & $3,698,623$ \\
\hline 2 & Osaka & Osaka & 1889-Apr 1 & 1956-Sep 1 & $2,547,316$ & $2,652,333$ \\
\hline 3 & Nagoya & Aichi & 1889-Oct 1 & 1956-Sep 1 & $1,336,780$ & $2,240,751$ \\
\hline 4 & Kobe & Hyogo & 1905-May 10 & 1956-Sep 1 & 979,305 & $1,556,491$ \\
\hline 5 & Kyoto & Kyoto & 1889-Apr 1 & 1956-Sep 1 & $1,204,084$ & $1,425,955$ \\
\hline 6 & Kita Kyushu $^{(\mathrm{M}, \mathrm{K})}$ & Fukuoka & 1963-Feb 10 & 1963-Apr 1 & 986,401 & 989,723 \\
\hline 7 & Sapporo $^{(\mathrm{A})}$ & Hokkaido & 1922-Aug 1 & 1972-Apr 1 & $1,010,123$ & $1,914,358$ \\
\hline 8 & Fukuoka $^{(\mathrm{A})}$ & Fukuoka & 1905-May 26 & 1972-Apr 1 & 853,270 & $1,420,184$ \\
\hline 9 & Kawasaki & Kanagawa & 1924-Jul 1 & 1972-Apr 1 & 973,486 & $1,404,532$ \\
\hline 10 & $\operatorname{Hiroshima}^{(\mathrm{A})}$ & Hiroshima & 1905-Jun 3 & 1980-Apr 1 & 899,399 & $1,171,559$ \\
\hline 11 & Sendai ${ }^{(A)}$ & Miyagi & 1905-Jun 12 & 1989-Apr 1 & 857,335 & $1,020,319$ \\
\hline 12 & Chiba & Chiba & 1921-Jan 1 & 1992-Apr 1 & 829,455 & 955,022 \\
\hline 13 & Saitama $^{(\mathrm{M})}$ & Saitama & 2001-May 1 & 2003-Apr 1 & $1,023,937$ & $1,226,487$ \\
\hline 14 & Shizuoka $^{(\mathrm{M}, \mathrm{C})}$ & Shizuoka & 1889-Apr 1 & 2005-Apr 1 & 469,695 & 726,060 \\
\hline 15 & Sakai $^{(A, C)}$ & Osaka & 1889-Apr 1 & 2006-Apr 1 & 792,018 & 849,547 \\
\hline 16 & Hamamatsu $^{(\mathrm{A}, \mathrm{C})}$ & Shizuoka & 1911-Jul 1 & 2007-Apr 1 & 582,085 & 820,971 \\
\hline 17 & Niigata $^{(\mathrm{A}, \mathrm{C})}$ & Niigata & 1889-Apr 1 & 2007-Apr 1 & 501,431 & 807,748 \\
\hline 18 & Okayama $^{(\mathrm{A}, \mathrm{C})}$ & Okayama & 1889-Jun 1 & 2009-Apr 1 & 626,642 & 699,160 \\
\hline 19 & Sagamihara ${ }^{(\mathrm{A}, \mathrm{C})}$ & Kanagawa & 1954-Nov 20 & 2010-Apr 1 & 605,561 & 712,604 \\
\hline 20 & $\operatorname{Kumamoto}^{(\mathrm{A}, \mathrm{C})}$ & Kumamoto & 1889-Apr 1 & 2012-Apr 1 & 662,012 & 728,332 \\
\hline
\end{tabular}

Sources: $[61,81]$.

${ }^{(1)}$ Authorization populations were based upon the Japanese Census preceding their special designation. For example, the 1990 Census population was used for Chiba. However, to show the impacts of mergers or annexations on these cities, 2000 Census original populations were utilized as the authorization population for the six cities reaching this status after Saitama. Kumamoto's authorization population represents its municipal estimate for April 1, 2010 (See the bolded numbers).

(A) Established through the annexation of adjacent municipalities.

${ }^{(\mathrm{C})}$ Formerly a Core City.

${ }^{(\mathrm{K})}$ Kitakyushu surpassed one million inhabitants in the 1965 Census.

${ }^{(\mathrm{M})}$ Established through the merger of two or more cities.

(T) The 23 Tokubetsu-Ku of Tokyo do not comprise a Government Ordinance Designated City, but are generally discussed along with them. Its authorization population was based upon the 1947 Census.

The first major response to the perceived benefits and expanded powers granted to million cities, occurred in 1963, when five cities in Fukuoka Prefecture-Moji, Wakamatsu, Yahata, Tobata, and Kokura-agreed to merge to create Japan's sixth Designated City, Kita Kyushu [68]. Over the next 17 years, Sapporo, Fukuoka, and Kawasaki in 1972, and then Hiroshima in 1980, also were authorized as Designated Cities. Kawasaki achieved one million inhabitants organically, growing as a result its location adjacent to the southern borders of Tokyo's $23 \mathrm{Ku}$, and the rapid suburbanization of the surrounding Shuto (national capital) Region, during the 1960s. The others attained their status through the annexation of numerous adjacent municipalities. Between 1955 and 1967, Sapporo incorporated five entire towns and villages, and parts of another within its territory. From 1954 to 1971, Fukuoka annexed 11 adjacent municipalities and parts of three others. On the other hand, Hiroshima engulfed nearly all of its metropolitan area. First, between 1955 and 1956, it added three villages. Then, in a calculated strategy by local and prefectural officials to attain Designated City status, between 1971 and 1975, it annexed 12 adjacent towns and one village. Both Sapporo and Hiroshima also had to obtain central government waivers related to the 2,000 persons per $\mathrm{km}^{2}$ requirement, as following their extensive annexation campaigns, neither was remotely close to the density threshold. From that point on, the central government repealed the density criteria; eventually, the less than $10 \%$ employment in primary industries requirement also was retracted from LAL [82].

Following Hiroshima, between 1980 and April 30, 2003, only two new Designated Cities, Sendai (in 1989) and Chiba (in 1992), were authorized, bringing the total to 12. Sendai achieved this status through the incorporation of one city, two towns, and one village. Conversely, Chiba, basically 
mirroring Kawasaki, grew as a result of the continued suburbanization of the Shuto Region during the 1970s and 1980s. Despite its fortuitous location, Chiba would also become the first city authorized as a Designated City to never reach one million inhabitants.

According to the strategic local government informants interviewed for this study, historically, there has been an implied caveat to the LAL's 500,000 population threshold requirement. In practice, the central government only granted Designated City status to municipalities which had already exceeded or were expected soon to surpass one million inhabitants [68]. Chiba's population accelerated rapidly from 482,133 in 1970 to 829,455 in 1990 , with only 176 of this gain attributed to annexations. As a result, at the time it was authorized as a Designated City, there was little doubt it would soon exceed one million. Its population stood at 924,319 for the 2005 Census, whereas municipal residential registry counts put it at 960,566, as of September $1,2010[83]$.

While significant at the time, the actions of the Japanese Government over the next 15 years eventually would make this point irrelevant. During this period, it would not only redefine the population standards for Designated Cities, but also pass several other national laws to stamp its own image on the nation's municipal hierarchy. In the process, it also would trigger a race for local power nationwide.

\section{1990s Decentralization Policies and the Race for Local Power in Japan, 2001-2010}

On May 15, 1995, after years of debate on the issue, the Japanese Diet (Congress) introduced the Law for the Promotion of Decentralization (DPL or Chiho Bunken Suishin Ho in Japanese). In order to ensure the smooth devolution of functional authority to localities, a Committee for the Promotion of Decentralization (CDP) also was established [84]. These actions were complemented and preceded on April 1, 1995, by the ten-year reauthorization of the Special Law for the Promotion of Municipal Mergers (Law no. 6, 1965), a statute which in the past had been utilized to offer incentives to small municipalities willing to amalgamate [84]. In addition, in June of that year, related amendments to LAL were made. Unfortunately, it would take another four years and a severe intergovernmental budget crisis before consensus was finally reached between the CDP and the central government ministries regarding the specific responsibilities to be devolved to municipalities [85]. Nevertheless, altogether, the provisions embedded within the above three revised statutes would serve to both create and to institutionalize a well-defined national urban hierarchy based upon population size, and to provoke a race for local status and power, during the 2000s [68].

One of the most significant measures introduced in the revised LAL was the authorization of a third tier of special status cities, to follow Tokyo's $23 \mathrm{Ku}$ and the Designated Cities in Japan's municipal hierarchy, to be called Chukakushi (Core Cities) [86]. Initially, under Article 252, Section 22 of LAL, to qualify for this classification a municipality had to
(1) have a population of 300,000 or more, (2) have a land area of at least $100 \mathrm{~km}^{2}$, and (3) be a key employment center in its region, with a greater daytime than nighttime population. If a city's population was 500,000 or above, it could petition for a waiver to the third requirement [37]. On April 1, 1996, 12 cities were approved as the nation's first Cores Cities and granted administrative and service authority above that of ordinary cities, but less expansive than that of the Designated Cities (see Table 2). In doing so, the central government hoped that by granting such cities additional powers, it would encourage other smaller municipalities to merge in order to attain this new status [68].

Meanwhile, while attempting to implement this national policy shift in intergovernmental authority, the nation's economic decline, which began during the early-1990s with the bursting of its stock and asset bubble, continued. In its wake, local revenues contracted significantly during the late 1990s, and a national budget crisis ensued. This led to major program cuts, including the dramatic reduction in national subsidies to local governments, especially the Local Allocation Tax [LAT]; the LAT has been distributed annually to municipalities and prefectures whose fiscal capacity was inadequate to meet national standards for essential public services [88]. This forced local governments to increase supplementary borrowing, so as to meet their required public services provisions. As a result, the proportion of total outstanding debt from local bonds, which stood at "roughly $100 \%$ of local government expenditures at the end of the 1980s," soared to $200 \%$ by 2001 [89, page 15]. This situation was worsened by the fact that the central government remained unwilling to relinquish any of its taxing authority to municipalities $[38,68,70,74]$.

Within the context of this double-edged local revenue squeeze, in May 1998, the central government decided to present its official Decentralization Promotion Plan to the Diet. Then, on July 8, 1999, the Diet reauthorized a revised DPL, by enacting the Omnibus Law for Decentralization (Chiho Bunken Ikkatsu $\mathrm{Ho}$ ), which included the amendment of 475 associated laws, and set April 1, 2000 as the date for the full implementation of the 60-plus finally agreed upon functions to be devolved to localities [85, 88, 90-92]. Among the administrative reforms delineated in this legislation were two important measures which would dramatically reshape Japan's national municipal hierarchy. The first called for the prompt reorganization and shrinkage in the number of municipalities. The second introduced a fourth tier of specially authorized cities, Tokurei-shi (Special Case Cities) [90]. Essentially in accordance with the latter, the central government also amended LAL in 1999, by eliminating the daytime/nighttime population requirement for Core Cities [84].

With relation to the reorganization of municipalities, leaders from the ruling Liberal Democratic Party (LDP) and the Ministry of Home of Affairs (MOHA, now the Ministry of Internal Affairs and Communications or MIC) declared that the nation should slash its number of municipalities from 3,229 to 1,000 , by the year 2005 [93]. Given the planned devolution of functions, the LDP and MOHA believed that this was the only possible way in which local 
Table 2: Progression of Japan's Chukaku-shi (Core Cities), April 1, 1996-April 1, 2011 ${ }^{(1)}$.

\begin{tabular}{|c|c|c|c|}
\hline Date authorized & City name (alphabetically listed) & Number authorized & Total \\
\hline April 1, 1996 & $\begin{array}{l}\text { Gifu, Hamamatsu, Himeji, Kagoshima, Kanazawa, } \\
\text { Kumamoto, Niigata, Okayama, Sakai, Shizuoka, } \\
\text { Toyama, Utsunomiya }\end{array}$ & 12 & 12 \\
\hline April 1, 1997 & Akita, Koriyama, Nagasaki, Oita, Wakayama & 5 & 17 \\
\hline April 1, 1998 & Fukuyama, Kochi, Miyazaki, Toyota & 4 & 21 \\
\hline April 1, 1999 & Iwaki, Nagano, Toyohashi, Takamatsu & 4 & 25 \\
\hline April 1, 2000 & Asahikawa, Matsuyama & 2 & 27 \\
\hline April 1, 2001 & Yokosuka & 1 & 28 \\
\hline April 1, 2002 & Nara, Kurashiki & 2 & 30 \\
\hline April 1, 2003 & $\begin{array}{l}\text { Funabashi }^{(\mathrm{w})}, \text { Kawagoe }^{(\mathrm{d})}, \text { Okazaki }^{(\mathrm{d})}, \text { Sagamihara }^{(w)} \text {, } \\
\text { Takatsuki }^{(\mathrm{d})} \\
\text { Shizuoka merges with Special Case City, Shimizu }\end{array}$ & 5 & 35 \\
\hline April 1, 2005 & $\begin{array}{l}\text { Higashi Osaka }{ }^{(\mathrm{w})} \\
\text { Shizuoka becomes a Designated City }\end{array}$ & 1 & 35 \\
\hline October 1, 2005 & Hakodate $^{(\mathrm{a}, \mathrm{t})}$, Shimonoseki $^{(\mathrm{m}, \mathrm{s})}$ & 2 & 37 \\
\hline April 1, 2006 & Sakai becomes a Designated City & & 36 \\
\hline October 1, 2006 & Aomori $^{(\mathrm{m})}$ & 1 & 37 \\
\hline April 1, 2007 & Hamamatsu and Niigata become Designated Cities & 0 & 35 \\
\hline April 1, 2008 & $\begin{array}{l}\operatorname{Kashiwa}^{(\mathrm{a}, \mathrm{w})}, \operatorname{Kurume}^{(\mathrm{a}, \mathrm{t})}, \text { Morioka }^{(\mathrm{a}, \mathrm{s})} \text {, } \\
\text { Nishinomiya }^{(\mathrm{a}, \mathrm{w})}\end{array}$ & 4 & 39 \\
\hline April 1, 2009 & $\begin{array}{l}\text { Amagasaki }^{(\mathrm{a}, \mathrm{t})}, \text { Maebashi } \\
\text { Okayama becomes a Designated City }\end{array}$ & 3 & 41 \\
\hline April 1, 2010 & Sagamihara becomes a Designated City & 0 & 40 \\
\hline April 1, 2011 & Takasaki $^{(\mathrm{a}, \mathrm{s})}$ & 1 & 41 \\
\hline April 1, 2012 & Kumamoto to become Designated City & & 40 \\
\hline
\end{tabular}

Source: [87].

Notes: ${ }^{(1)}$ The seven cities in italics have been promoted to Designated City.

(a) Achieved the status by annexing adjacent municipalities.

(b) Originally authorized after the elimination of the daytime/nighttime requirement.

${ }^{(m)}$ Achieved the status by merging with adjacent municipalities. Shimonoseki and Aomori are listed as mergers by the MIC but were existing Special Case Cities which essentially annexed adjacent areas.

${ }^{(\mathrm{s})}$ Formerly a Special Case City.

(w) Qualified only after revisions were made to the $100 \mathrm{~km}^{2}$ requirement.

governments could efficiently provide their citizens with an adequate level of administrative, welfare, and other public services [38]. To facilitate the process, the Diet again revised the Municipal Merger Law and instructed the MOHA to offer preferential extraordinary financial subsidies to those localities which committed to amalgamate by the Act's March 31, 2005 expiration date; these incentives were later extended until March 2010 [84, 94, 95]. Downtown revitalization, the installation of communications infrastructure, and the construction and renovation of public housing, transit, roads, parks, and waste disposal sites all were eligible projects for this special funding [96-98]. Meanwhile, in August 1999, the MOHA asked each prefectural government to compile a list of potential mergers within their territory $[68,99]$.
As for the second measure, according to Article 252, Section 26-3 of LAL, in order to be classified as a Special Case City, an area had to have a population of 200,000 or more [82]. Thereafter, its city council and prefectural assembly were required to jointly petition the MIC for this designation; a similar petition has been required of Designated and Core Cities. The first ten Special Case Cities were officially recognized in November 2000, and then granted a subset of the functions devolved to Core Cities (see Table 3). Although not formally acknowledged, much like the Core Cities, a municipality's level of employment, and thereby its fiscal capacity to handle these new responsibilities, also was an important consideration for those cities qualifying for Special Case City status. As a result, not all cities with 200,000 
Table 3: Progression of Japan's Tokurei-shi (Special Case Cities) November 1, 2000-April 1, $2011^{(1)}$.

\begin{tabular}{|c|c|c|c|}
\hline Date authorized & City name (alphabetically listed) & Number authorized & Total \\
\hline Nov 1, 2000 & $\begin{array}{l}\text { Fukui, Hakodate, Kofu, Kure, Matsumoto, Morioka, Numazu, Odawara, } \\
\text { Yokkaichi, Yamato }\end{array}$ & 10 & 10 \\
\hline April 1, 2001 & $\begin{array}{l}\text { Amagasaki, Fuji, Hachinohe, Hirakata, Hiratsuka, Ibaraki, Kasugai, } \\
\text { Kawaguchi, Kurume, Maebashi, Mito, Neyagawa, Otsu, Sasebo, Shimizu, } \\
\text { Suita, Takasaki, Toyonaka, Yamagata, Yao }\end{array}$ & 20 & 30 \\
\hline April 1, 2002 & $\begin{array}{l}\text { Akashi, Atsugi, Ichinomiya, Kakogawa, Kishiwada, Shimonoseki, } \\
\text { Tokorozawa, }\end{array}$ & 7 & 37 \\
\hline April 1, 2003 & $\begin{array}{l}\text { Chigasaki, Koshigaya, Takarazuka } \\
\text { Shimizu merges with Core City, Shizuoka }\end{array}$ & 3 & 39 \\
\hline April 1, 2004 & Soka & 1 & 40 \\
\hline Oct 1,2005 & $\begin{array}{l}\text { Tottori }^{(\text {a) }} \\
\text { Hakodate and Shimonoseki become Core Cities }\end{array}$ & 1 & 39 \\
\hline April 1, 2007 & Isesaki $^{(m)}$, Joetsu $^{(\mathrm{a})}$, Nagaoka $^{(\mathrm{a})}, \mathrm{Ota}^{(\mathrm{m})}$, Tsukuba $^{(\mathrm{a})}$ & 5 & 44 \\
\hline April 1, 2008 & $\begin{array}{l}\text { Kasukabe } \\
\text { Kurume, and Morioka become Core Cities }\end{array}$ & 1 & 43 \\
\hline April 1, 2009 & $\begin{array}{l}\text { Kumagaya }^{(a)} \\
\text { Amagasaki, Maebashi, and Otsu become Core Cities }\end{array}$ & 1 & 41 \\
\hline April 1, 2011 & Takasaki becomes a Core City & & 40 \\
\hline
\end{tabular}

Source: [100].

Notes: ${ }^{(1)}$ The nine cities in parenthesis have risen to Core City status or above by April 1, 2010.

(a) Achieved the status by annexing adjacent municipalities. ${ }^{(\mathrm{m})}$ Achieved the status by merging with adjacent municipalities. Ota is listed as a merger by the MIC, but it was a city of 147,000 residents in 2000 that essentially annexed three adjacent towns.

or more inhabitants have applied for this fourth-tier special designation [68].

Outside of the authorization of Special Case Cities, and an increase in the number of Core Cities to 27, by the middle of 2000, central government measures had provoked little change in the attitudes of local officials toward amalgamations. As a result, the number of municipalities remained at 3,229. This situation began to change in September of that year, however, when officials from three above average income cities in Saitama Prefecture with a combined population of 1.02 million-Urawa, Omiya, and Yono-announced that they had signed a formal agreement to amalgamate, effective May 1, 2001. This was a significant statement, as Omiya and Urawa had for 70 years publicly disagreed regarding the issue of merging. The impetus for the change in their position was twofold: (1) a promise from the central government to transfer an important regional bureau complex to the area and (2) the chance to create Saitama City, its prefecture's first Government Ordinance Designated City. Officials believed that attaining this status would greatly enhance the area's profile in the eyes of firms and residents, and therefore, foster economic growth during a period of national decline. According to one official interviewed, becoming a Designated City was equivalent to reaching the major leagues, and is the ultimate goal of all major cities in Japan [68].
According to The Japan Times [101], within 13 months of Saitama's September 5, 2000 agreement, 1,657 municipalities were discussing possible mergers. By September 1, 2002 , this total had grown to 2,495 or $77.5 \%$ of the nation's then 3,218 localities [96]. This represented a sharp increase from 1998, when only four percent of the nation's localities were considering potential amalgamations [102]. Moreover, according to the MIC [103], 130 legal mergers committees, involving 536 municipalities, were formed between September 5, 2000 and October 1, 2002. These totals then soared to 219 committees and 906 municipalities, respectively, by March 2003, and eventually to 521 and 1,437 by March 7, 2005 [103].

According to press reports, this rush to form merger committees was directly related to the March 31, 2005 expiration date of the extraordinary subsidies offered by the revised 1999 Municipal Merger Law (i.e., fear among local officials that their communities would be deprived of their fair share of these funds) [104]. Interestingly, the majority of those municipalities not discussing mergers were small towns and villages, especially those with less than 10,000 people, many of which were targeted for consolidation [102]. Conversely, cities were searching for merger partners, with many viewing the potential benefits accrued by achieving a higher status in the national urban hierarchy as highly attractive [68]. 
Perhaps sensing this, in April 2002, the central government again amended LAL by waiving the $100 \mathrm{~km}^{2}$ provision to become a Core City, for cities of 500,000 or more inhabitants; it repealed it altogether in April 2005 [105]. The revised LAL also granted more expansive authority to cities within all three special classifications. Additionally, the informal population requirement for Designated Cities was reduced from one million to 700,000 , although the legal limit still remained at 500,000. This prompted the cities of Shizuoka and Shimizu to merge in 2003, in order to become Japan's 14th Designated City on April 1, 2005 (see Tables 1 and 3). A year later, Sakai also was acknowledged, followed by Hamamatsu and Niigata in 2007, Okayama in 2009, and Sagamihara in 2010. Finally, Kumamoto was approved, effective April 1, 2012. The latter will increase the total number of Designated Cities to 20, eight of which were newly authorized in just a nine-year period (2003-2012). By comparison, only 12 were sanctioned in the first 47 years of the classification's history.

The Designated Cities classification was originally created to provide large cities with special authority to enable them to better address the unique problems that they possessed as a result of their size. While this was still a factor, by 2005 , the primary impetus compelling cities to merge or annex their way to a population of 700,000 had become the perks expected from a "promotion" to a higher status in the national municipal hierarchy [68]. Further evidence of this was the fact that all seven of the above-mentioned cities already had become Core Cities, a category of municipalities which was granted similar powers to pre-1995 Designated Cities. This especially was the case for Shizuoka, Hamamatsu, Niigata, and Sagamihara. As highlighted in Table 1, Shizuoka was a city of 469,695 before its merger with Shimizu, and Sagamihara expanded by 107,000 residents through its annexations. Hamamatsu annexed 11 municipalities and Niigata 14 , and thereby added 238,000 and 306,000 residents, respectively, in order to surpass 700,000 residents and become Designated Cities [68]. In the process, the latter two effectively incorporated their entire metropolitan areas within their corporate boundaries.

According to local officials, the expanding status and authority granted to larger cities also provoked consolidations among smaller communities seeking to reach the population thresholds for Core and Special Case Cities. As presented in Table 2, including Kumamoto, on April 1, 2011, there will be 41 Core Cities, up from 27 in 2000. Among the 17 Core Cities authorized since April 1, 2003, the first six achieved this classification only after the elimination of the daytime/nighttime population criteria or the relaxation of the $100 \mathrm{~km}^{2}$ area requirement. The last 11, all of which have been authorized since October 1, 2005, were promoted only after either annexing or merging with adjacent municipalities. Eight of these were previously Special Case Cities. Two of the three others, Kashiwa and Nishinomiya, only were designated after the elimination of the $100 \mathrm{~km}^{2}$ requirement.

As for the Special Case Cities, as again shown in Table 3, on April 1, 2011, there will be 40, up from 10 in 2000 . This total does not include Takasaki, or the eight other cities which previously were promoted to a higher-order status. Among the eight newly authorized since October 1, 2005, seven reached 200,000 after annexations or amalgamations. As illustrated in Table 4, these mergers were part of a race for local power in Japan, which resulted in the number of municipalities nationwide falling from 3,190 on April 1, 2003 (i.e., a month prior to the authorization of Saitama as the 13th Designated City), to 1,727 on April 1, 2010. In the process, the number of cities increased from 677 to 786 , while the total number of towns and villages declined from 2,513 to 941 . The former was aided by a special provision to Municipal Merger Law, which lowered the population milestone for ordinary city status from 50,000 to 30,000, for those municipalities involved in a merger by March 31, 2010 [92].

Finally, in regards to the 686 ordinary cities, 757 towns, and 184 villages currently in existence, officials interviewed for this paper suggested that they could be stratified into a hierarchy of: cities with between 100,000 and 199,999 in population, followed by cities with fewer than 100,000, followed by towns, and then finally, villages. Prefectural ordinances, rather than national laws, have determined whether a village can become a town [68]. In most cases, both have the same statutory authority, with a town merely defined as a more densely populated area [70]. Nevertheless, officials interviewed for this study believed that superior governments and citizens regarded towns as having a higher status than that of villages [68].

In sum, the decentralization efforts of the Japanese Government, in concert with its utilization of population as the primary measure for classifying municipalities, have served to expand, refine, further institutionalize the nation's municipal hierarchy. Within this context, central policies enacted to aggressively facilitate the reorganization of municipalities served to set off a race for local power during the 2000s. In other words, while the impacts of global forces on municipalities may have expanded, Japan's municipal hierarchy historically has been, and has remained, deeply nested within its own particular national context.

\section{Conclusion}

Since the second edition of Peter Hall's book World Cities in 1979, and animated especially following the publication of John Friedmann's 1986 "World City Hypothesis", the urban scholarship has debated whether or not TNC led global economic forces to have disembedded cities from their national urban systems. The main counter-argument to the World/Global City paradigm has come from Nested City theorists, particularly those studying cities situated within East Asia's developmental states. The most vocal critics have been scholars of Japanese cities, who have argued that the Japanese State has continued to maintain primacy over urban growth trajectories and processes within its territory. In other words, they have claimed that Japanese municipalities have not been disembedded from their national urban hierarchy, nor have they been reterritorialized into a world city network in which the Japanese State has lost control over their form and function. 
TABle 4: Progression of Municipalities in Japan, 1883-2010 (selected years).

\begin{tabular}{|c|c|c|c|c|c|c|c|c|}
\hline Date & Total & Cities & Towns & Villages & $\begin{array}{c}\text { Designated } \\
\text { Cities }\end{array}$ & $\begin{array}{l}\text { Core } \\
\text { Cities }\end{array}$ & $\begin{array}{c}\text { Special Case } \\
\text { Cities }\end{array}$ & $\begin{array}{c}\text { Ordinary } \\
\text { Cities }\end{array}$ \\
\hline $\operatorname{Dec} 31,1883$ & 71,497 & - & - & - & & & & \\
\hline $\operatorname{Dec} 31,1889$ & 15,859 & 39 & - & - & & & & 39 \\
\hline Dec 31, 1908 & 12,448 & 61 & 1,167 & 11,220 & & & & 61 \\
\hline Dec 1, 1940 & 11,498 & 178 & 1,706 & 9,614 & & & & 178 \\
\hline Oct 1,1945 & 10,520 & 205 & 1,797 & 8,518 & & & & 205 \\
\hline $\operatorname{Jan} 1,1951$ & 9,868 & 252 & 1,891 & 8,226 & & & & 252 \\
\hline Sept 1, 1956 & 3,975 & 498 & 1,870 & 1,574 & 5 & & & 493 \\
\hline April 1, 1966 & 3,372 & 560 & 2,011 & 801 & 6 & & & 554 \\
\hline April 1, 1996 & 3,232 & 666 & 1,990 & 576 & 12 & 12 & & 642 \\
\hline Nov 1, 2000 & 3,229 & 671 & 1,991 & 567 & 12 & 27 & 10 & 622 \\
\hline April 1, 2001 & 3,226 & 672 & 1,987 & 567 & 12 & 28 & 30 & 602 \\
\hline April 1, 2003 & 3,190 & 677 & 1,961 & 552 & 13 & 35 & 39 & 590 \\
\hline April 1, 2004 & 3,100 & 695 & 1,872 & 533 & 13 & 35 & 40 & 607 \\
\hline April 1, 2005 & 2,395 & 739 & 1,317 & 339 & 14 & 35 & 40 & 650 \\
\hline April 1, 2006 & 1,820 & 779 & 844 & 197 & 15 & 36 & 40 & 688 \\
\hline April 1, 2008 & 1,788 & 783 & 812 & 193 & 17 & 39 & 43 & 684 \\
\hline April 1, 2009 & 1,777 & 783 & 802 & 192 & 18 & 41 & 41 & 683 \\
\hline April 1, 2010 & 1,727 & 786 & 757 & 184 & 19 & 40 & 41 & 686 \\
\hline Sept 6, 2010 & 1,727 & 786 & 757 & 184 & 19 & 40 & 41 & 686 \\
\hline
\end{tabular}

Sources: $[72,106,107]$.

Notes: ${ }^{(\mathrm{k})}$ For some reason, the $23 \mathrm{Ku}$ of Tokyo have never been included in the government's municipal count.

— or blank represents not defined at the time.

So which view best reflects the current situation of Japanese cities? This study investigated this question, and drawing upon historical accounts, national statutes governing municipalities, and interviews with more than 100 nonelected local officials, it arrived at a similar conclusion to that of Nested City theorists. Japan's municipal hierarchy has evolved and continues to be shaped by a combination of institutional factors embedded within its particular political-economic context. This paper demonstrated this, by offering examples of how Japan's municipal stratification system was initially formed by the roles certain areas played in the country's political-economic history. This included (1) serving as the main settlements of imperial, military, or bureaucratic rule, (2) being selected as an important port and/or industrial centers during the country's modernization period, (3) growing in response to strategic policies, decrees were made by the feudal or civil national government, and (4) acting as important production and/or employment centers during the nation's rapid postwar economic expansion. This paper further supported its claims by chronicling how national laws regarding municipalities have produced, refined, expanded, and formalized Japan's municipal hierarchy, primarily based upon an area's population size, but also considering its employment base.

Lastly, it showed how recent changes to Japan's intergovernmental context, specifically post-1995 central government policies to devolve functional authority to municipalities, ignited a race for local power during the 2000s. The result was a significant rise in the number of specially authorized cities (Designated, Core, and Special Case Cities), as well as ordinary cities, accompanied by a 46 percent contraction in the number of localities between 2003 and 2010, accomplished through amalgamations and annexations; the number of towns and villages was cut by nearly two-thirds. In other words, while the impact of global forces may have significantly expanded in recent times, Japan's municipalities have remained deeply nested within their national municipal hierarchy. It also appears doubtful that this situation will change anytime soon, as according to local officials, the central government, despite devolving a fair amount of functional authority, has continued to refuse to provide its municipalities with a great share of tax revenues collected, nationwide [68]. 


\section{Acknowledgments}

The author would like to thank Takayuki Namiki, Shuko Kimura Jacobs, Jennifer B. Jacobs, Paul Waley, Ben Derudder, the local government officials interviewed, and the USR reviewers for their comments and advice related to this article. He would also like to acknowledge Hiroshi Fukuda, as well as Hosei University's Faculty of Business, International Center, and library staff, for their funding, friendships, and support over the years. All of which helped make it possible for the author to complete his field work for this article.

\section{References}

[1] P. Hall, The World Cities, McGraw-Hill, New York, NY, USA, 2nd edition, 1979, the first edition was published in 1966.

[2] R. Cohen, "The new international division of labor: multinational corporations and urban hierarchy," in Urbanization and Urban Planning in Capitalist Society, M. Dear and A. Scott, Eds., pp. 287-315, Methuen, London, UK, 1981.

[3] J. Friedmann and G. Wolff, "World city formation: an agenda for research and action ( urbanization process)," International Journal of Urban \& Regional Research, vol. 6, no. 3, pp. 309-344, 1982.

[4] B. Derudder, P. J. Taylor, F. Witlox, and G. Catalano, "Hierarchical tendencies and regional patterns in the world city network: a global urban analysis of 234 cities," Regional Studies, vol. 37, no. 9, pp. 875-886, 2003.

[5] J. Friedmann, “The world city hypothesis," Development \& Change, vol. 17, no. 1, pp. 69-83, 1986.

[6] S. Sassen, The Global City, Princeton University Press, Princeton, NJ, USA, 1991.

[7] S. Sassen, Cities in a World Economy, Pine Forge, Thousand Oaks, Calif, USA, 1994.

[8] P. L. Knox and P. J. Taylor, Eds., World Cities in a World System, Cambridge, UK, 1995.

[9] D. A. Smith and M. Timberlake, "Conceptualising and mapping the structure of the world system's city system," Urban Studies, vol. 32, no. 2, pp. 287-302, 1995.

[10] D. A. Smith and M. F. Timberlake, "World city networks and hierarchies, 1977-1997: an empirical analysis of global air travel links," American Behavioral Scientist, vol. 44, no. 10, pp. 1656-1678, 2001.

[11] P. J. Taylor, "Hierarchical tendencies amongst world cities: a global research proposal," Cities, vol. 14, no. 6, pp. 323-332, 1997.

[12] P. Taylor, World City Network: A Global Urban Analysis, Routledge, New York, NY, USA, 2004.

[13] J. Feagin and M. Smith, "Cities and the new international division of labor: an overview," in The Capitalist City, M. Smith and J. Feagin, Eds., pp. 3-34, Blackwell, Cambridge, UK, 1987.

[14] P. Taylor, G. Catalano, and N. Gane, "A geography of global change: cities and services, 2000-2001," Urban Geography, vol. 24, pp. 431-441, 2003.

[15] P. Taylor, B. Derudder, P. Saey, and F. Witlox, Eds., Cities in Globalization: Practices, Policies and Theories, Routledge, New York, NY, USA, 2006.

[16] P. Taylor et al., Ed., Global Urban Analysis: A Survey of Cities in Globalization, Earthscan, London, UK, 2010.

[17] J. V. Beaverstock, R. G. Smith, and P. J. Taylor, "A roster of world cities," Cities, vol. 16, no. 6, pp. 445-458, 1999.
[18] B. Derudder et al., "Pathways of change: shifting connectivities in the world city network, 2000-2008," Urban Studies, vol. 47, no. 9, pp. 1861-1877, 2010.

[19] K. H. Shin and M. Timberlake, "World cities in Asia: cliques, centrality and connectedness," Urban Studies, vol. 37, no. 12, pp. 2257-2285, 2000.

[20] J. Abu-Lughod, New York, Chicago, Los Angeles: America's Global Cities, University of Minnesota Press, Minneapolis, MN, USA, 1999.

[21] M . Smith, Transnational Urbanism: Locating Globalization, Blackwell, Malden, Mass, USA, 2001.

[22] C. Chase-Dunn, "The system of world cities, A. D. 800-1975," in Urbanization in the World-Economy, M. Timberlake, Ed., pp. 269-291, Academic Press, Orlando, Fla, USA, 1985.

[23] R. Preston, "The structure of central place systems," in Systems of Cities: Readings on Structure, Growth, and Policy, L. Bourne and J. Simmons, Eds., pp. 185-206, Oxford, UK, 1978.

[24] L. Bourne and J. Simmons, Eds., Systems of Cities: Readings on Structure, Growth, and Policy, Oxford University Press, New York, NY, USA, 1978.

[25] R. C. Hill and K. Fujita, "The nested city: introduction," Urban Studies, vol. 40, no. 2, pp. 207-217, 2003.

[26] R. C. Hill, "Cities and nested hierarchies," International Social Science Journal, vol. 56, no. 181, pp. 373-384, 2004.

[27] R. C. Hill and K. Fujita, "Osaka's Tokyo problem," International Journal of Urban \& Regional Research, vol. 19, no. 2, pp. 181-193, 1995.

[28] K. Fujita, "A world city and flexible specialization: restructuring of the Tokyo metropolis," International Journal of Urban \& Regional Research, vol. 15, no. 2, pp. 269-284, 1991.

[29] K. Fujita, "Neo-industrial Tokyo: urban development and globalisation in Japan's state-centred developmental capitalism," Urban Studies, vol. 40, no. 2, pp. 249-281, 2003.

[30] R. C. Hill and J. W. Kim, "Global cities and developmental states: New York, Tokyo and Seoul," Urban Studies, vol. 37, no. 12 , pp. 2167-2195, 2000.

[31] T. Machimura, "The urban restructuring process in Tokyo in the 1980s: transforming Tokyo into a world city," International Journal of Urban \& Regional Research, vol. 16, no. 1, pp. 114-128, 1992.

[32] T. Machimura, "Symbolic use of globalization in urban politics in tokyo," International Journal of Urban and Regional Research, vol. 22, no. 2, pp. 192-194, 1998.

[33] T. Machimura, "Narrating a 'global city' for 'new Tokyoites," in Japan and Britain in the Contemporary World, H. Dobson and G. Hook, Eds., pp. 196-212, Routledge, New York, NY, USA, 2003

[34] K. Miyamoto, "Japan's world cities: Osaka and Tokyo compared," in Japanese Cities in the World Economy, K. Fujita and R. C. Hill, Eds., pp. 53-82, Temple University, Philadelphia, $\mathrm{Pa}, \mathrm{USA}, 1993$.

[35] J. W. White, "Old wine, cracked bottle? Tokyo, Paris, and the global city hypothesis," Urban Affairs Review, vol. 33, no. 4, pp. 451-477, 1997.

[36] R. Cybriwsky, Tokyo: The Shogun's City at the Twenty-First Century, Wiley, New York, NY, USA, 1998.

[37] A. J. Jacobs, "Devolving authority and expanding autonomy in Japanese prefectures and municipalities," Governance, vol. 16, no. 4, pp. 601-623, 2003.

[38] A. J. Jacobs, "Federations of municipalities: a practical alternative to local government consolidations in Japan?" Governance, vol. 17, no. 2, pp. 247-311, 2004. 
[39] A. J. Jacobs, "Has central Tokyo experienced uneven development? An examination of Tokyo's $23 \mathrm{Ku}$ relative to America's largest urban centers," Journal of Urban Affairs, vol. 27, no. 5, pp. 521-555, 2005.

[40] A. J. Jacobs, "Embedded localities: employment decline, inner city population growth, and declining place stratification among Japan's mid-size and large cities," City \& Community, vol. 5, no. 3, pp. 269-282, 2006.

[41] A. J. Jacobs, "Developmental state planning, sub-national nestedness, and reflexive public policymaking: keys to employment growth in Saitama City, Japan," Cities, vol. 25, no. 1, pp. 1-20, 2008.

[42] P. Waley and N. Fieve, "Introduction- Kyoto and Edo-Tokyo: urban histories in parallels and tangents," in Japanese Capitals in Historical Perspective, N. Fieve and P. Waley, Eds., pp. 1-40, Routledge Curzon, New York, NY, USA, 2003.

[43] A. Saito, "Global city formation in a capitalist developmental state: Tokyo and the waterfront sub-centre project," Urban Studies, vol. 40, no. 2, pp. 283-308, 2003.

[44] C. H. Wang, "Taipei as a global city: a theoretical and empirical examination," Urban Studies, vol. 40, no. 2, pp. 309-334, 2003.

[45] J. H. Wang, "World City Formation, geopolitics and local political process: Taipei's ambiguous development," International Journal of Urban and Regional Research, vol. 28, no. 2, pp. 384-400, 2004.

[46] T. Tsukamoto and R. Vogel, "Rethinking globalization: the impact of central governments on world cities," in Governing Cities in a Global Era, R. Hambleton and J. Gross, Eds., pp. 15-31, Palgrave Macmillan, New York, NY, USA, 2007.

[47] P. Waley, "Tokyo-as-world-city: reassing the role of capital and the state in urban restructuring," Urban Studies, vol. 44, no. 8, pp. 1465-1490, 2007.

[48] A. Sorensen, J. Okata, and S. Fujii, "Urban renaissance as intensification: building regulation and the rescaling of place governance in Tokyo's high-rise manshon boom," Urban Studies, vol. 47, no. 3, pp. 556-583, 2010.

[49] D. Kornhauser, Urban Japan: Its Foundations and Growth, Longman, New York, NY, USA, 1976.

[50] H. Nakamura, "Urban growth in prewar Japan," in Japanese Cities in the World Economy, K. Fujita and R. C. Hill, Eds., pp. 26-49, Temple University Press, Philadelphia, Pa, USA, 1993.

[51] D. W. Edgington, “Osaka," Cities, vol. 17, no. 4, pp. 305-318, 2000.

[52] M. Berry, Hideyoshi, Harvard University Press, Cambridge, Mass, USA, 1982.

[53] S. Eisenstadt, Japanese Civilization: A Comparative View, University of Chicago Press, Chicago, Ill, USA, 1996.

[54] C. Mosk, Japanese Industrial History: Technology, Urbanization, and Economic Growth, M.E. Sharpe, Armonk, NY, USA, 2001.

[55] A. J. Jacobs, "Max Weber was right about the preconditions, just wrong about Japan: the Japanese ethic and its spirit of capitalism," The Open Area Studies Journal, vol. 3, pp. 12-29, 2010.

[56] S. Yamaguchi, "Japan: towards a new metropolitan policy," Cities, vol. 1, no. 5, pp. 474-486, 1984.

[57] Y. Kato, Yokohama: Past and Present, Yokohama City University, Yokohama, Japan, 1990.

[58] D. Edgington, "Economic restructuring in Yokohama: from gateway port to international core city," Asian Geographer, vol. 10, no. 1, pp. 62-78, 1991.
[59] Kanagawa Prefecture, The history of Kanagawa, Kanagawa Prefectural Government, Office of Administration and Coordination, Yokohama, Japan, 1985.

[60] TMG, Port of Tokyo 2009, Tokyo Metropolitan Government, Bureau of Port and Harbor, Tokyo, Japan, 2009, http:// www.kouwan.metro.tokyo.jp/english/portoftokyo2009/index .html.

[61] Unless otherwise specified, all municipal populations cited in the text were obtained from their respective census year. See: Government of Japan, Population census of Japan 19502005. Tokyo: Japan Statistical Association, 1951-2006. This includes pre-1950 figures cited, which were drawn from the 1950 Census. Table 1 for Designated Cities provides sources for their current populations. Similarly, unless otherwise noted, all employment figures cited were obtained from: Government of Japan, 2006 establishment and enterprise census of Japan. Tokyo: Japan Statistical Association, 2008.

[62] AJS, Japanese Cities: A Geographical Approach, The Association of Japanese Geographers, Tokyo, Japan, 1970.

[63] K. Murata and I. Ota, An Industrial Geography of Japan, St. Martin's Press, New York, NY, USA, 1980.

[64] J. Eyre, Nagoya: The Changing Geography of a Japanese Regional Metropolis, Studies in Geography no. 17, University of North Carolina, Chapel Hill, 1982.

[65] K. Fujita, "The technopolis: high technology and regional development in Japan," International Journal of Urban \& Regional Research, vol. 12, no. 4, pp. 566-594, 1988.

[66] D. Edgington, "Planning for technology development and information systems in Japanese cities and regions," in Planning for Cities and Regions in Japan, P. Shapira, I. Masser, and D. Edgington, Eds., pp. 126-154, Liverpool University Press, Liverpool, UK, 1994.

[67] J. McClain and O. Wakita, Eds., Osaka: The Merchants' Capital of Early Modern Japan, Cornell University Press, Ithaca, NY, USA, 1999.

[68] Interviews with Local Government Officials, Author Interviews with 150 local officials in Aichi, Chiba, Gifu, Hiroshima, Hyogo, Mie, Saitama, Shizuoka, and Tokyo Prefectures, June 1998 to July 2009.

[69] K. Steiner, Local Government in Japan, Stanford University Press, Stanford, Calif, USA, 1965.

[70] Y. Isozaki, Ed., The Local Administration in Japan, Local Autonomy College, Tokyo, Japan, 1997.

[71] Nihon Kajo Shuppan, Kyu shi-cho-son mei binran: Meiji 22nen kara genzai made [Old city, town and village names handbook: 1889 to the present], Nihon Kajo Shuppan, Tokyo, Japan, 1999.

[72] Shi-cho-son Yoran Henshu Iinkai [Municipal Directory Editing Committee], Heisei 21-nen, zenkoku shi-cho-son yoran [2009 national municipal directory], Daiichi Hoki, Tokyo, Japan, 2009.

[73] M. Muramatsu, Local Power in the Japanese State, University of California, Berkeley, Calif, USA, 1997.

[74] T. MacDougall, "Towards political inclusiveness: the changing role of local government," in Local Government Development in Post-War Japan, M. Muramatsu, F. Iqbal, and I. Kume, Eds., pp. 30-62, Oxford University Press, New York, NY, USA, 2001.

[75] R. Samuels, The Politics of Regional Policy in Japan: Localities Incorporated? Princeton University Press, Princeton, NJ, USA, 1983. 
[76] Jinbunsha, Ed., Senzen Showa Tokyo sanpo: kochizu library bessatsu, kochizu genadaizu de aruku [A walk thru prewar Showa Tokyo: old map library additional volume, walk with old and modern maps], Jinbunsha, Tokyo, Japan, 2004.

[77] JCLA, Revised Local Autonomy Law, Japan Center for Local Autonomy, Tokyo, Japan, 2000, http://www.soumu.go.jp/ kokusai/sonota.html.

[78] T. Kamo, "Time for reform? Fifty years of postwar Japanese local self-government," in Japan: Eyes on the Country, Views of the 47 Prefectures, Foreign Press Center, Japan, Ed., pp. 8-17, Foreign Press Center, Tokyo, Japan, 1997.

[79] T. Kamo, "An aftermath of globalisation? East Asian economic turmoil and Japanese cities adrift," Urban Studies, vol. 37, no. 12, pp. 2145-2165, 2000.

[80] C. Hein and P. Pelletier, Eds., Cities, Autonomy, and Decentralization in Japan, Routledge, New York, NY, USA, 2006.

[81] Designated Cities, "Population and the number of households by the basic residential registers, as well as the number of foreign residents, as of the 1st of every month," [In Japanese]. April 1, 2010 data was obtained from the websites of all 20 Designated Cities. For example, see Kumamoto city, http://www.city.kumamoto.kumamoto.jp/.

[82] Government of Japan, Chiho Jichi Ho [Local Autonomy Law], E-Gov, Tokyo, Japan, 2010, http://law.e-gov.go.jp/htmldata/ S22/S22HO067.html.

[83] Chiba city, "Current population, as of September 1, 2010," December 2010, http://www.city.chiba.jp/sogoseisaku/sogoseisaku/tokei/jinkou.html.

[84] H. Kido and E. Nakamura, "Why municipalities in Japan refused amalgamation?" in Canadian Political Science Association Conference, May 2007.

[85] B. Barrett, "Decentralization in Japan: negotiating the transfer of authority," Japanese Studies, vol. 20, no. 1, pp. 33-48, 2000.

[86] M. Mabuchi, "Municipal amalgamations," in Local Government Development in Post-War Japan, M. Muramatsu, F. Iqbal, and I. Kume, Eds., pp. 185-206, Oxford, UK, 2001.

[87] MIC, Chukaku-shi taisho-shi ichiran [Core city qualifiers list], Government of Japan, Ministry of Internal Affairs and Communications, Tokyo, Japan, 2010, http://www.soumu.go.jp/ main_content/000019091.pdf.

[88] H. Ikawa, 15 Years of Decentralization Reform in Japan, Council of Local Authorities for International Relations, Tokyo, Japan, 2008.

[89] T. Mano, "Obstacles to decentralization must embrace independence," The Japan Times, vol. 21, p. 15, August 2001.

[90] S. Furukawa, "Decentralization in Japan," in Japan's Road to Pluralism: Transforming Local Communities in the Global Era, S. Furukawa and T. Menju, Eds., pp. 21-45, Japan Center for International Exchange, Tokyo, Japan, 2003.

[91] K. Yokomichi, The Development of Municipal Mergers in Japan, Council of Local Authorities for International Relations, Tokyo, Japan, 2007.

[92] MIC, Local Government System in Japan, Government of Japan, Ministry of Internal Affairs and Communication, Tokyo, Japan, 2007.

[93] The Japan Times, "LDP works out city merger strategy," The Japan Times, July 2000, http://www.japantimes.co.jp/.

[94] A. Rausch, "The Heisei dai gappei: a case study for understanding the mergers of the Heisei era," Japan Forum, vol. 18, no. 1, pp. 133-156, 2006.
[95] MIC, White Paper on Local Public Finance 2002, Illustrated: FY2000 Settlement, Government of Japan, Ministry of Internal Affairs and Communications, Financial Management Division, Local Public Finance Bureau, Tokyo, Japan, 2002.

[96] MIC, Local Administration, Government of Japan, Ministry of Internal Affairs and Communications, Tokyo, Japan, 2002.

[97] The Japan Times, "Ministry to promote city mergers," The Japan Times, April 2001, http://www.japantimes.co.jp/.

[98] The Japan Times, "Infrastructure spending key to town mergers," The Japan Times, August 2001, http://www.japantimes.co.jp/.

[99] The Japan Times, "Number of municipalities could be slashed by $81 \%$," The Japan Times, December 2000, http:// www.japantimes.co.jp/.

[100] MIC, Tokurei-shi Taisho-shi Ichiran [Special Case City Qualifiers List], Government of Japan, Ministry of Internal Affairs and Communications, Tokyo, Japan, 2010, http://www .soumu.go.jp/main_content/000019093.pdf.

[101] The Japan Times, "More than half of Japan's cities consider mergers," The Japan Times, October 2001, http://www.japantimes.co.jp/.

[102] The Japan Times, "Municipalities leaning toward mergers," The Japan Times, January 2002, http://www.japantimes.co .jp/.

[103] MIC, Gappei kyogikai secchi no jyokyo [Current state of establishing merger committees], Government of Japan, Ministry of Internal Affairs and Communication, Tokyo, Japan, 2005, http://www.soumu.go.jp/gapei/gapei3.html.

[104] Y. Wijers-Hasegawa, "Shonan merger plan races clock, though some balk," The Japan Times, February 2002, http:// www.japantimes.co.jp/.

[105] MIC, Chukaku-shi yoken no hensen [Changes to the requirements for becoming a core city], Government of Japan, Ministry of Internal Affairs and Communications, Tokyo, Japan, 2010, http://www.soumu.go.jp/cyukaku/pdf/ cyukaku_01.pdf.

[106] Shi-cho-son Jichi Kenkyukai [Municipal Local Autonomy Study Group], Heisei 13-nen, Zenkoku Shi-cho-son Yoran [2001 National Municipal Directory], Daiichi Hoki, Tokyo, Japan, 2001.

[107] MIC, To-do-fu-ken betsu Shi-cho-son su no Henson: Heisei 11nen, 03-31 [Change in number of municipalities by prefecture: Since March 31, 1999], Government of Japan, Ministry of Internal Affairs and Communications, Tokyo, Japan, 2010, http://www.soumu.go.jp/kouiki/kouiki.html. 


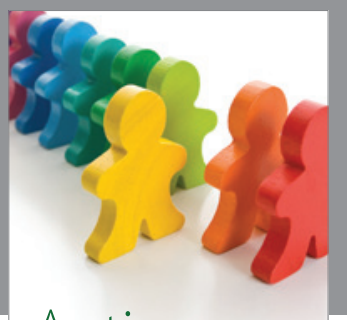

Autism

Research and Treatment
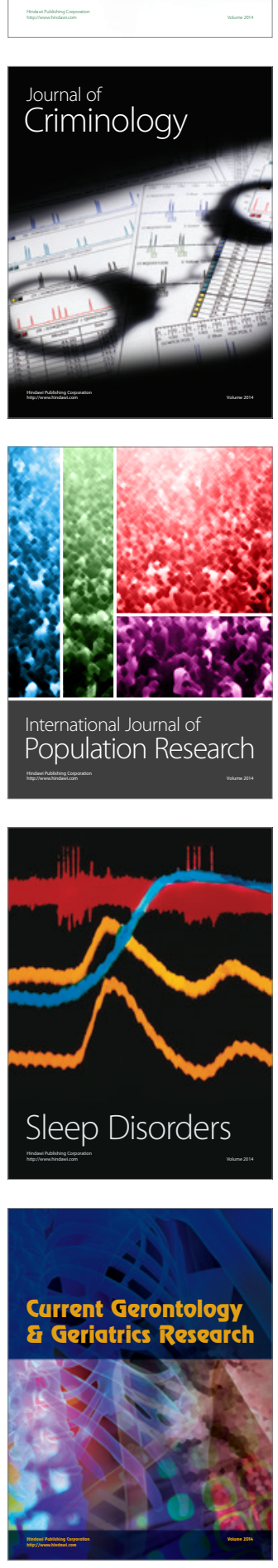
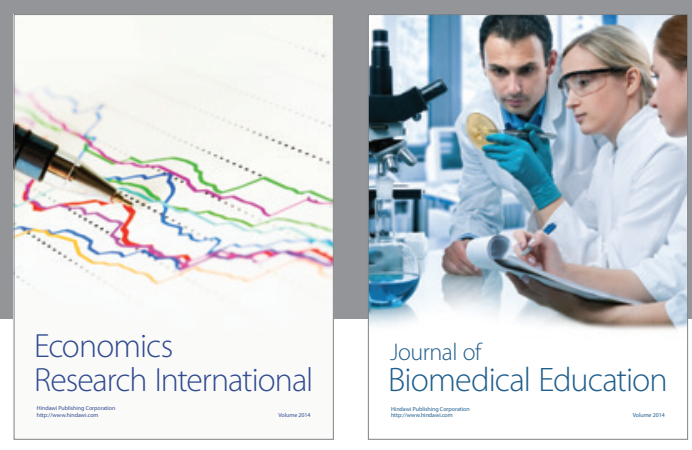

Journal of

Biomedical Education

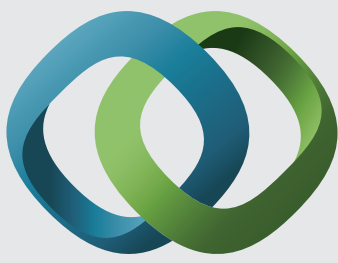

\section{Hindawi}

Submit your manuscripts at

http://www.hindawi.com
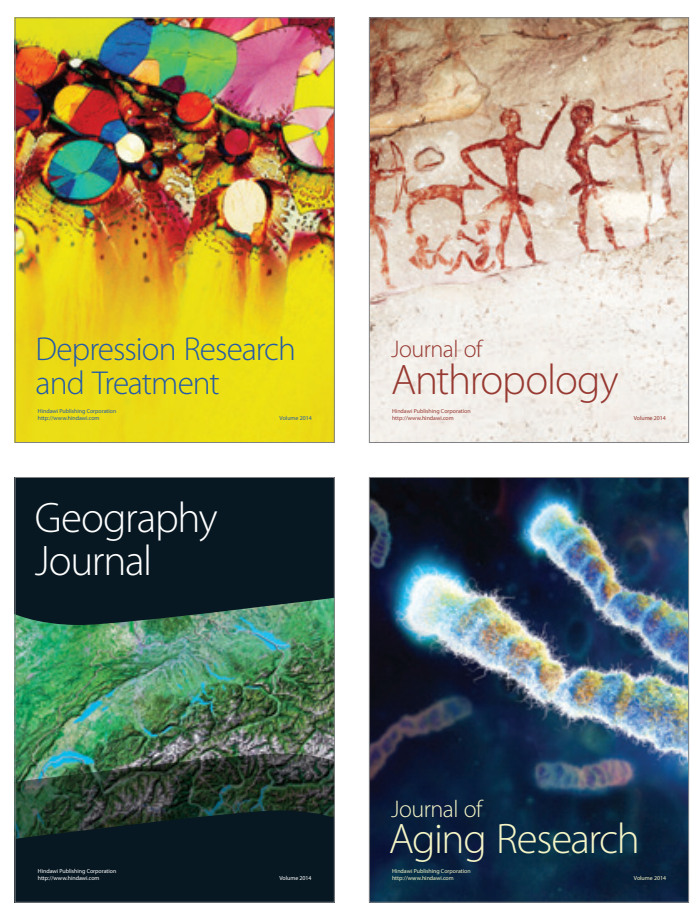

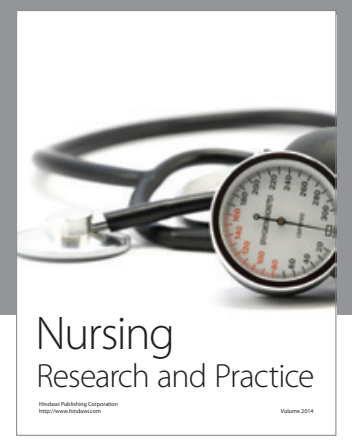

Nursing

Research and Practice

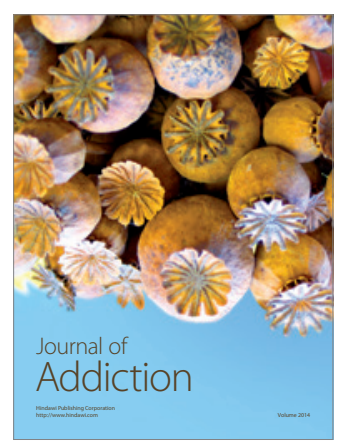

Child Development

Research

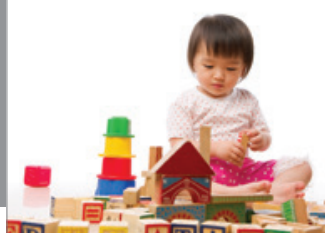

迥
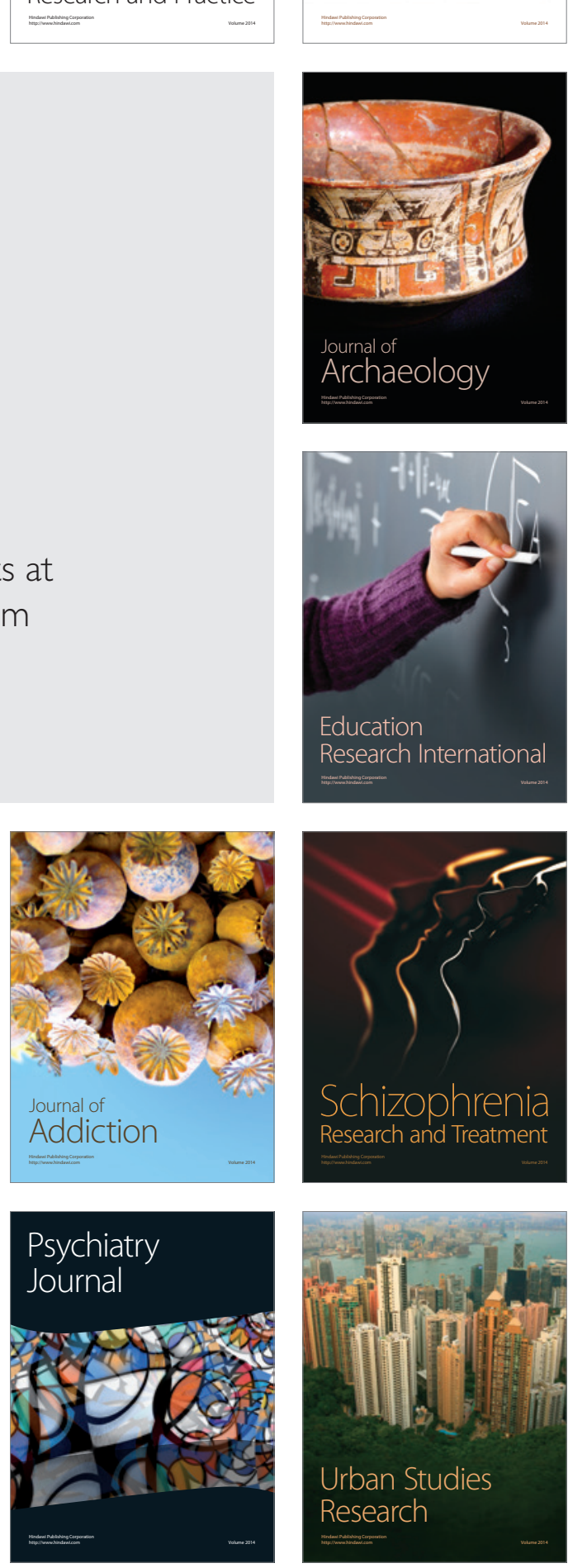